2. Stein PD, Woodard PK, Weg JG et al. Diagnostic pathways in acute pulmonary embolism: recommendations of the PIOPED II Investigators. Radiology 2007. 242: 15-21.

3. Torbicki A, Perrier A, Konstantinides S et al. Guidelines on the diagnosis and management of acute pulmonary embolism: the Task Force for the Diagnosis and Management of Acute Pulmonary Embolism of the European Society of Cardiology (ESC). Eur Heart J 2008; 29: 2276-315

4. Regitz-Zagrosek V, Blomstrom Lundqvist C, Borghi C et aL. ESC Guidelines on the management of cardiovascular diseases during pregnancy: the Task Force on the Management of Cardiovascular Diseases during Pregnancy of the Euro pean Society of Cardiology (ESC). Eur Heart J 2011; 32: 3147-97.

5. Jacobsen AF, Sandset PM. Venous thromboembolism associated with pregnancy and hormonal therapy. Best Pract Res Clin Haematol 2012: 25: 319-32.

6. Bettmann MA, Baginski SG, White RD et al. ACR Appropriateness Criteria ${ }^{\circledR}$ acute chest pain-suspected pulmonary embolism. J Thorac Imaging 2012; 27 W28-31.

\title{
H. Hatle og medarbeidere svarer:
}

Vi er ikke uenig i den algoritmen som Aaløkken og medarbeidere skisserer når det gjelder akutt håndtering og utredning av mulig alvorlig lungeemboli. Vi synes det er fint at de kommer med strålehygienisk vurdering av pulmonal CT-angiografi hos gravide. Vi mener også det er viktig å merke seg at gravide må utredes på samme måte som andre pasienter når de blir akutt syke.

Som beskrevet vil ikke ekkokardiografi fremstille den pulmonale karsengen som ved pulmonal CT-angiografi. Hos denne pasienten ble den kliniske observasjonen av den respiratoriske/sirkulatoriske utviklingen og anamnestiske opplysninger styrende, og dette medførte at mistanken om lungeemboli ble klart svekket. I lys av dette ble pulmonal CT-angiografi ikke utført akutt eller i de påfølgende dagene. Valget av MR var trolig av strålehygieniske årsaker, men vi fikk informasjonen vi var ute etter. Vi er ikke uenig i at CT trolig kunne gitt svaret tidligere.

Kommentaren til Aaløkken og medarbeidere er god og av generell art. Hos den individuelle pasienten vil man fortløpende gjøre vurderinger med vekt på utviklingen av den kliniske situasjonen. Det ble gjort hos denne pasienten under nøye overvåkning, og symptomene ble avklart med en uventet diagnose som resultat.

\section{Håvard Hatle}

havarhat@gmail.com

Dag Arne Lihaug Hoff

Inge Lode

Åse Roald Sandvik

Jan Gunnar Hatlebakk

Håvard Hatle (f. 1984) er lege i spesialisering. Ved aktuelle hendelse var han turnuslege ved Kvinneklinikken, Ålesund sjukehus.

Ingen oppgitte interessekonflikter.

Dag Arne Lihaug Hoff (f. 1965) er ph.d. og spesialist i indremedisin og i fordøyelsessykdommer, med særskilt kompetanse i nevrogastroenterologi og motilitet. Han er overlege, forskningsveileder i Helse Møre og Romsdal og sitter i styret for Scandinavian Association of Neurogastroenterology and Motility.

Ingen oppgitte interessekonflikter.

Inge Lode (f. 1959) er spesialist i radiologi og overlege.

Ingen oppgitte interessekonflikter.

Åse Roald Sandvik (f. 1971) er spesialist i fødselshjelp og kvinnesykdommer og overlege.

Ingen oppgitte interessekonflikter.

Jan Gunnar Hatlebakk (f. 1959) er spesialist i indremedisin og i fordøyelsessykdommer og overlege.

Ingen oppgitte interessekonflikter 